\title{
INTERCULTURAL FRIENDSHIP AS STRATEGY TO REDUCE ANXIETY AND UNCERTAINTY OF ZIMBABWE STUDENTS IN MUHAMMADIYAH SURAKARTA UNIVERSITY
}

\author{
Khusnul Khatimah \\ Prodi Ilmu Komunikasi, Universitas Muhammadiyah Surakarta \\ Email: Khatimahk9@gmail.com
}

\begin{abstract}
Intercultural friendship is a more specific and more complex phenomenon that has its own characteristics in terms of relationships. The meeting between two different cultures in building a relationship of intercultural friendship. Establish intercultural friendship relationships with local people by immigrants as a form of adaptation to the new environment. Immigrants are individuals who move from one region to another in a country influenced by push factors and pull factors such as economic, environmental, and educational factors. Immigrants can experience several conditions when they are in a new environment such as feelings of anxiety and uncertainty to interact with the surrounding environment. This study aims to find out how the relationship of intercultural friendship can reduce the level of anxiety and uncertainty of Zimbabwean students at the Muhammadiyah Surakarta University. The research method used qualitative method. In the research of intercultural friendship relationships as a strategy to reduce anxiety and uncertainty of Zimbabwean students at the University Muhammadiyah of Surakarta, researchers divide the results of research into 5 categories. first, the language barrier as the cause of anxiety. Secondly, the lack of information about the new environment as a cause of uncertainty. Third is the relationship of friendship as a way to reduce anxiety and uncertainty. Fourthly, to increase the intensity of communication to get friends. The last is the confidence to interact in interpersonal communications.
\end{abstract}

Keywords: Adaptation, Migration , Anxiety, Uncertainty, Intercultural, Friendship.

\begin{abstract}
ABSTRAK
Pertemanan antarbudaya merupakan fenomena yang lebih spesifik dan lebih kompleks yang memiliki ciri sendiri dalam hal menjalin hubungan. Dengan adanya pertemuan antara dua budaya yang berbeda dalam membangun sebuah hubungan pertemanan antarbudaya. Menjalin hubungan pertemanan antarbudaya dengan penduduk setempat dilakukan oleh beberapa pendatang atau imigran sebagai bentuk adaptasi mereka terhadap lingkungan baru. Imigran merupakan individu yang melakukan perpindahan dari suatu wilayah menuju wilayah di negara lain yang dipengaruhi oleh faktor pendorong dan faktor penarik seperti faktor ekonomi, lingkungan dan pendidikan. Imigran dapat mengalami beberapa kondisi ketika mereka berada di lingkungan baru seperti perasaan cemas dan ketidakpastian untuk berinteraksi dengan lingkungan sekitar. Penelitian ini bertujuan untuk mengetahui bagaimana hubungan pertemanan antarbudaya dapat mengurangi tingkat kecemasan dan ketidakpastian mahasiswa Zimbabwe di Universitas muhammadiyah Surakarta. Metode penelitian yang digunakan adalah kualitatif. Dalam penelitian hubungan pertemanan antarbudaya sebagai strategi untuk mengurangi kecemasan dan ketidakpastian mahasiswa Zimbabwe di Universitas Muhammadiyah Surakarta, peneliti membagi hasil penelitian menjadi 5 kategori. pertama, hambatan bahasa sebagai penyebab kecemasan. Kedua, kurangnya informasi tentang lingkungan baru sebagai penyebab ketidakpastian. Ketiga adalah hubungan pertemanan sebagai cara untuk mengurangi kecemasan dan
\end{abstract}


ketidakpastian. Keempat, meningkatkan intensitas komunikasi untuk mendapat teman. Yang terakhir adalah kepercayaan untuk berinteraksi dalam komunikasi antarpribadi.

Kata Kunci: Adaptasi, Migrasi , Kecemasan, Ketidakpastian, Pertemanan, Antarbudaya.

\section{A. INTRODUCTION}

Imigration is the movement of the population from one region to another region in another country to remain temporarily or permanently (Munir, 1981). Individuals who migrate to other countries are influenced by push factors and pull factors such as economic, environmental and educational factors (Lee, 1978). In the current education factor is not only Indonesian students who choose to continue their education abroad, but many foreign students who are interested to study in Indonesia. This will have a positive impact for educational institutions in Indonesia including universities. Improved learning methods at college will be required to meet international strandarts (Nurani, 2015).

Muhammadiyah Surakarta University is one of universities in Indonesia which is oriented towards global scale co-ops. In 2010 UMS established an international program and double degree program that can facilitate foreign students who want to study in Indonesia. The international class program is a regular curriculum course that uses English or Arabic as the introduction. While the double degree program is the result of cooperation between the Muhammadiyah Surakarta University with partner abroad universities.

Currently Muhammadiyah Surakarta University educates more than 27.000 students consisting of vocational program students, Strata 1, Magister and Doctor programs. The students not only come from areas in Indonesia such as Kalimantan, Sumatra, Sulawesi, and Papua. But it also has foreign students from Thailand, Philippines, Japan, Jordan, Libya, Palestine, Romania, Zimbabwe, Sudan, Uganda, Madagascar and Slovakia. UMS students come from different regions and countries so that ums students consist of diverse cultures. They come from different regions, tribes, races, and religions.

Quoted from Solopos.com in 2011 Muhammadiyah Surakarta University began to promote universities in the African region an effort to attract international students. In 2016 there is an international class student who came from Zimbabwe then in 2017 the number of students from Zimbabwe increased to 3 students. The three students are students of the UMS scholarship program. One student from Zimbabwe join in international class of strata 1 program and two students are magister students.

Students from Zimbabwe will come together with students from other countries as well as students who mostly come from Indonesia, not only in the campus but also in residential environment where they can meet people from different countries and tribes. Cultural differences will be encountered by students in the campus or residence, but it is expected that effective communication can be established between different cultures. Without understanding the concept of intercultural communication, it allows the failure to establish good relationships. Intercultural communication is communication between people of different cultures, whether in terms of race, ethnicity or socio-economic differences (Tubbs \& Moss, 2005).

The Republic of Zimbabwe is a country in southern Africa that has $98 \%$ population of black ethnic group of majority with the Shona ethnic group. Culture is a way of life that developed and embraced by a group of people and takes place from generation to generation where in intercultural communication, language becomes the root principle of intercultural communication (Tubbs, 1996). The national languages used in Zimbabwe are English, Shona, and Ndbele. While in Indonesia the national language used by the people 
is Indonesian. In addition to using the Indonesian language, Indonesia also has 726 local languages, of which the most widely spoken languages for speaking is Java language, especially in Java such as the city of Surakarta (Sugiyono, 2012).

When immigrants first come to destination country they will have expectations of a new environment. However, when they encounter drastic differences in their habits, negative responses will arise such as depression, frustration, and disorientation caused by anxiety or uncertainty fear in a new cultural environment (Dayaksini, 2004). The process of cultureshock usually experienced by some immigrants. Culture shock can be overcome by adaptation. Intercultural adaptation process in the form of an interactive process that develops through the communication activities of foreigners with a new socio-cultural environment. Intercultural adaptation is reflected by the compatibility between Zimbabwean student communication pattern and the communication pattern expected by the indonesian students and the local culture. Adaptation is done to reduce the level of anxiety and uncertainty by immigrants experiencing culture shock (Kim, 2003).

Uncertainty and anxiety in the intercultural communication is caused by the weaknesses adapting in the environment. The less knowledge about other cultures in new environment, the more uncertain and anxiety. Management uncertainty and anxiety become an important focus in intercultural communication (Littlejohn, 2002).

Zimbabwean students can adapt in the form of management of anxiety and uncertainty in intercultural communication, if the interaction between Zimbabwean students in the new environment can well done with the establishment of a friendship relationship that creates a feeling of comfort and minimize anxiety and uncertainty in the new environment. The friendship between two different cultures is a part of the relationship of friendship in interpersonal communication, the intercultural friendship develops from the low stage starting from the introduction to the higher friendship stage of being a close friend. In the context of intercultural friendship, cultural differences can be an attraction for students to establish friendships.

Research (Peng, 2011) "Intercultural Friendship Development Between Finnish and International Students" in a thesis at the University of Jyväskylä Finland, based on studies in building relationships of friendship development and the development of intercultural friendship to understanding the process of forming intercultural friendship and factors involved in the formation of friendships between Finnish students and international students. Journal shows that intercultural friendship is formed along with the norms, values and roles in a relationship, while when viewed from the theory of cultural negotiation, behavior is more focused on cultural understanding in general.

Journal of "Intercultural Analysis of Communication Anxieties Encountered by International Students in the United States" (Wang, 2010). In the journal explained that the learning process involving international students from China with their mentors from America at the United States higher education institutions have different cultures and differences of feelings, thoughts, anxiety, and expectations. The results of this study provide a comparison that the level of anxiety of international student communication from China is higher in the discussion class that requires students to understand the social situation in the United States. But the level of concern in international or English language classes is lower than their mentors.

Research with journals has an equation that focuses on the intercultural and interpersonal aspects of communication between students of different countries and cultures aimed at identifying the anxiety that arises when intercultural interactions in international education and the factors that cause anxiety arise. While the difference 
is the purpose of research journals that compare the level of anxiety communication between students and mentors. This study looks at how intercultural friendship can reduce the level of anxiety and uncertainty in the intercultural communication of students from Zimbabwe.

In addition to the above journal of intercultural communication research by (Jumasani, 2013) "Self Management To Manage Uncertainty and Anxiety In Intercultural Communication Students of West Kalimantan". In this study aimed to gain an understanding of the processes and barriers in adaptation by students from West Kalimantan in Surakarta. This study discusses the general picture of West Kalimantan students in strategy, involvement of others, implementation of communication management to manage uncertainty and anxiety, then evaluated from students and society. The similarity with this research is in the use of the theory of management of anxiety and uncertainty of intercultural communication.

The research aims to know how the relationship of intercultural friendship into a strategy to reduce the anxiety and uncertainty of Zimbabwean students at the University muhammadiyah Surakarta?

\section{B. LITERATURE REVIEW}

\section{Culture Shock and Adaptation}

Culture shock is interference experienced when immigrants face cultural differences in foreign environments with the usual culture they encounter in their environment. The interference can cause tension, frustration, guilt and low self esteem that will make the individual feel uncomfortable when in a new environment or group, this can make the individual is alienated (Hayqal, 2011).

To resolve the culture shock adjusted a new environment is adaptation. Adaptation in intercultural communication studies is generally associated with changes from individuals or parts of groups. Everyone's motivation to adapt is different. The ability of Zimbabwean students to communicate in accordance with the norms and cultural values that exist in Indonesia depends on their adaptation process. However, Zimbabwean students must face the challenge of adapting to be beneficial to the environment. Zimbabwean students are also required to adaptation processes when meeting or interacting with different environments and cultures(Gudykunts, 1988).

The ability of individuals to communicate according to local cultural norms and values, depends on the outcome of the adaptation process undertaken. Basically every individual will adapt to different cultures or habits with their, to make theirself comfortable. This happens because intercultural adaptation is a thing that is already owned by individuals naturally and universally. There are several important things in the adaptation of openness, strength, and the ability to think positively from immigrants as well as from the local cultural environment. Adaptation is a collaboration of local entrants and local environments. The attainment of maximum intercultural adaptation is when individual migrants and individual local cultures mutually accept their culture with each other.

\section{Intercultural Friendship}

A friendship relation is a relationship between voluntarily wounded individuals where the role of a friend has no coercion such as the role of the individual in the family that is bound to the role (Wright, 1991). In Wright's definition, individuals in friendship have the responsibility to be emotionally supportive, actively providing assistance, maintaining the confidence of others and supporting each other (Wright, 1991).

Intercultural friendship has the function, form and character offriendship relationships determined by different cultures. In the journal by (Li, 2010)"Intercultural Friendship between Chinese and American ", the pattern of Chinese friendship is influenced by strong social obligations, commitment, 
and social help, while Americans tend to regard friendships as socializing, sharing, and searching activities. Friendships have benefits with different ways individuals engage in relationships. Benefit in friendship usually include skills in activity, emotional support, and help. However, unlike other relationships, friendship is more than a mutually beneficial relationship, but a sense of affection exchanged between individuals in the relationship and friendship gives a sense of satisfaction (Argyle \& Henderson, 1984).

The development of intercultural friendship is a more specific and more complex phenomenon, which has its own characteristics in terms of relationships. A model in the development of friendships consisting of three processes: systematic collection of information about spouse personality, construction, and modification, reconstruction of partner personality models, and an assessment of the level of support for a person's based on the similarity between a person's personality and his or her spouse's personality (Duke, 1975).

Three stages in the development of intercultural friendship: Trial, Enmeshment, and Renegotiation. These stages illustrate the supporting and strategies (Cupach \& Imahori, 1993). The Trial Stage is an experimentinanearlymeeting ofintercultural relationships that try to balance cultural differences and roles in relationships. In the Enmeshment stage refers to the transfer of cultural identity to build a relational culture. The Renegotiation stage of the process of mutual support and understanding of each other's cultural identity affects the feeling of mutual understanding (Lee, 2008).

\section{Anxiety and Uncertainty Management}

In interacting in different environments, Zimbabwean students will try to establish social relationships supported by the effectiveness of communication between Zimbabwean students and peoples in campus and residence. The effectiveness of intercultural communication is influenced by the uncertainty and anxiety in interacting.
Anxiety as a feeling of uneasiness, tension, and worried that a person feels about what will happento theirself. This anxiety can create a motivation to communicate and if managed properly can create an effective communication. In intergroup communication condition, anxiety tends to be higher than interpersonal communication condition. However, Anxiety is dynamic and tends to decline when their feel comfortable with the person (Stephan, 1985).

Uncertainty occurs when it is between two conditions on the one hand, the individual strongly believes in the prediction, whereas on the other hand, what will happen can be highly unpredictable (Marris, 1996). This uncertainty is cognitive and reduces the effectiveness of communication so it must be managed properly. If the situation can not reduce the uncertainty, it must be able to reduce itself. Uncertainty will be felt greater when communicating with strangers compared with ingroup members themselves. The theory that will be used as a reference researcher in analyzing the management of uncertainty and anxiety is AUM (Anxiety Uncertainty Management).

Anxiety Uncertainty Management Theory (Gudykunts, 1988) This theory is the development of the URT (Uncertainty Reduction Theory). (Berger \& Calabrese, 1975) mentions that the main thing when meeting a new person is the reduction in uncertainty that is seeing how uncertainty and anxiety occur in different cultural situations. Each culture tries to reduce uncertainty at certain stages of a relationship, but in a different way. The reduction of uncertainty in individuals from different cultures is influenced by experience and language acquisition factors. Experience and friendship with people from different cultures can increase confidence when facing individuals from other groups or foreigners. Also when mastering the local language language skills can help in tolerating the things that are ambiguous. So it can be concluded that with experience and mastery of language can increase self- 
confidence and not too panic to meet with someone from different groups so that will work well and can get information and reduce uncertainty (Littlejohn, 2002).

Superficial causes are surface factors that contribute to the underlying problem of anxiety and uncertainty in intercultural meetings. Anxiety Uncertainty Management Theory has axiom that presents a causal relationship with the anxiety and uncertainty that usually occurs in intercultural communication. Anxiety Uncertainty Management Theory are divided into seven sections as factors that cause anxiety and uncertainty: self-concept, motivation to interact, reactions to others, social categorization of foreigners, situational processes, relationships with strangers, and ethical interactions (Grifin, 2006).

\section{METHOD}

This research used qualitative research method by using population from foreign students at Muhammadiyah Surakarta University by using purposive sampling technique that is sampling based on student's from country of origin Zimbabwe (Notoatmodjo, 2010). This research uses qualitative method of content analysis on the phenomenon of foreign student communication which is studied by defining the communication process part on communicator aspects (Mayring, 2000). Content analysis in this research is done by inductive approach to find categorization based on data.

Credibility and validity criteria from content analysis concept comprehensively and intersubjectively, by using inter-coded reliability and triangulation of data source and theory. Triangulation with a data source that is comparing and checking of an information obtained through time and different tools (Patton, 1987: 331).

\section{RESULT AND DISCUSSION}

Based on data that has been interpreted from interviews with foreign students from Zimbabze on the research about the management of anxiety and uncertainty in created relationships between cultures, has obtained several themes that will explain the results of this research is language barrier as the cause of anxiety, lack of information about the new environment as a cause of uncertainty, friendship relationship as a way to reduce anxiety and uncertainty, increase the intensity of communication to get friends, Confidence to interact in interpersonal communication.

\section{Result}

\section{Language barrier as the cause of anxiety and uncertainty}

Anxiety experienced by foreign students from Zimbabwe is caused by several factors such as differences in language, food, and temperature. This difference of language, temperature, and food is not only considered as a trigger of anxiety and uncertainty in informants, but also a constraint or inhibiting factor that makes them difficult to live life in Indonesia.

"Most Indonesian people do not speak English, while I am very bad at Indonesian language, I use English in daily life"(Informant 2)

Among the factors causing anxiety such as language, food, and temperature. Language is one of the most influential obstacle in the interaction process of Zimbabwean students with Indonesian society. Language is an arbitrary vowel symbol system that enables everyone in a particular culture to study the cultural system in communicating or interacting (Finoechiaro, 1964). Between culture one and other, language as one of the distinguishing characteristics because by using the language then every group that exist in society can be itself as a unity different from other groups (Saussure, 1915).

Language reflects culture, the greater of culture differences influence of the uncertainty in ambiguity of intercultural communication. In intercultural communication seeks to reduce this uncertainty so as to better decipher, predict, and explain the behavior of others. More 
uncertainty and ambiguity require more time and effort to reduce uncertainty and to communicate more meaningfully (liliweri, 2007).

The national language that used in the Republic of Zimbabwe is English as well as other languages such as Shona and Ndebele (Mumbengegwi, 2015). While in Indonesia, especially in the city of Surakarta most of the people use Indonesian language and Javanese language in their daily life and in the campus environment UMS.

"The obstacle is the Indonesian language speaks too fast "(Informant 1)

In intercultural communication, language becomes one of the obstacles that can cause anxiety in communicating because in communication made to obtain information to be hampered by the existence of language differences. The reduction of anxiety and uncertainty in individuals from different cultures is influenced by language experience and mastery. If the mastery of local languages is high then the ability of the language can help in tolerating things that are ambiguous. Language acquisition can increase confidence and reduce anxiety to meet with people from different groups, so they can get more information and reduce anxiety and uncertainty (Littlejohn, 2000).

"I really wanted to talk to them and be friends, but they did not want to talk to me because they were different languages. In my country, I am used English in school and everyday, but in Indonesian English is not easy because they are usual to using Indonesian and regional languages such as Javanese "(Informant 3)

According to informants, the ability of Indonesian peoples in English is still very less because of the differences in language habits used in everyday life. In the formal education environment such as in Indonesia using indonesian language as an introduction to the learning process that makes them not trained to fluent in English as an international language. some Indonesians who do not speak English will choose not to communicate with foreigners. People who choose to avoid and not interact make the language as the main obstacle that raises anxiety will fail in establishing good relations and uncertainty in understanding the language of the intercultural communication process by Zimbabwean students in Indonesia.

\section{Lack of information about the new environment as a cause of uncertainty}

Beside to the raise of anxiety, Zimbabwean students also experience inner uncertainty when interacting. Uncertainty is the inability of a person to predict or explain the behavior, feelings, attitudes, or values of others. While anxiety refers to feelings of discomfort, tension, worry, or anxiety about something that will happen (Griffin, 2006). The effectiveness of intercultural communication depends on the level of uncertainty of a person in their new environment, the less information or knowledge of the environment and the people around their higher level of uncertainty that leads to lack of effectiveness of someone in intercultural situations (Littlejohn \& Foss, 2011).

"In the first year I want to go home because I feel everything is different and I do not know the situation here" (Informant 2)

In social situations there are two prominent forms of uncertainty: cognitive uncertainty and behavioral uncertainty. Cognitive uncertainty occurs when the individual feels unsure of the confidence or beliefs of others. While the uncertainty of behavior occurs when the individual feels unsure of the attitude of self or other person's attitude. Uncertainty occurs when the individual does not have adequate information about the surrounding environment. Zimbabwean students who are studying at UMS that they have never come or stayed in Indonesia before. In addition, they also do not know anyone when coming to Indonesia so that references or information about the condition of environtment in Indonesia is very little. 
"Im alone because I did not know everyone when I first came to Indonesia" (Informant 1)

Uncertainty experienced by Zimbabwean students is an uncertainty that occurs because the informant does not have adequate information about the surrounding environment. Uncertainty in Zimbabwean students has an effect on their behavior that tends to be passive and silent at the beginning of interaction.

\section{Friendship Relationship As A Ways To Reduce Anxiety And Uncertainty}

Effort to make friendships as multidimensional in traits that serve individuals in a variety of ways to gain pleasure, hope, and minimize anxiety that provide affective support in emotional (Rubin, 2004). The relationship of intercultural friendship is not so different from the concept of interpersonal friendship, the relationship of intercultural friendship of the involved individuals has the responsibility to be emotionally supportive, actively providing assistance, maintaining the confidence of others and supporting each other (Wright, 1991).

"I can get knowledge, information, and confidence because I have a different skin color but with having many friends can make me more confident" (Informant 3)

More confidence they can gain when having a friendship relationship with the host because they can be supported emotionally and needs so as to minimize anxiety in intercultural communication (Wright, 1991). Characters in intercultural friendship are determined by different cultures ( $\mathrm{Li}, 2010)$. The informant defines the friendship relationship that is distinguished into friends and close friends

"A friend is someone who can share knowledge and interact with them. can sometimes advise me. If I have a problem, a friend can say that I have to do this and that but some friends also can not advise me "(Informant 1)

"A close friend is someone who knows me more deeply than a friend. I want to be myself and not lie about myself in making friends. "(Informant 2)

The pattern of friendship by Zimbabwean students with Indonesians is influenced by social needs or relief factors, where informants can give each other benefits and information that can reduce the uncertainty of informants to the environment. The meaning of close friends given by informants based on their level of confidence in the individual, where friends defined people they know and often interact while close friends based on trust. The three stages of intercultural friendship made by the first Zimbabwean students are Trial, which is an experiment in the initial meeting as it is acquainted with Indonesians in balancing cultural differences and roles in relationships. the second is the Enmeshment stage that refers to the movement to build a relational culture such as the way they greet friends, Zimbabwean students use Indonesian language that follows the customs in their environment. The third is the Renegotiation stage of mutual support and understanding between Zimbabwean and Indonesian students (Lee, 2008).

"Yes, now I have Indonesian friends and I also have a close friend from Indonesia. We trust each other and can tell our secrets without worrying "(Informant 1)

The meaning of friends according to Zimbabwean students is differentiated into friends and close friends. A friend is someone they know and meet often but not based on trust while their close friends have faith. In reducing anxiety and uncertainty friends and close friends have the same contribution in providing information and help to learn Indonesian while in emotional support they get motivation from close friends, such as when they are desperate or need entertainment by traveling with close friends from indonesia to get to know Indonesia more closely.

Intercultural friendship is a special relationship of friendship between individuals with different national cultures, who are voluntarily and benefit as normal 
friends in the same cultural context. The formation of intercultural friendship is more challenging than intracultural friendship for various reasons such as cultural and linguistic differences (Huang, 2008). The reduction in uncertainty occurs when individuals have the motivation to reduce uncertainty (Littlejohn \& Foss, 2009). Self concept and competence of intercultural communication that is motivation, knowledge and skill. Factors such as anxiety, perceived social distance, ethnocentrism, and prejudice can influence a person's decision to communicate with others. If fear, dislike, and anxiety are more prominent, then someone will have negative motivation, and will avoid interaction with others (Gudykunst \& Mody, 2002).

"I do not know everything but my friend in class told me how to go by bus and I can learn the language with them. At least when I speak the wrong language, they will give correction." (Informant 2)

By being friendship relationships Zimbabwean students can learn Indonesian and friends from Indonesia can provide the information they need. A friendship relationship is a relationship between voluntarily wounded individuals where the role of a friend has no coercion such as the role of the individual in the family that is bound to the role obligation. The motivation to engage in intercultural friendship relationships with zimbabe students is a set of feelings, wants, needs, and encouragement associated with anticipation or involvement in new environments (Wright, 1991).

\section{Increase the intensity of communication to get friends}

Even Though they feelings of anxiety and uncertainty with strangers, Zimbabwean students try to encourage themselves to begin communication. This happens because they realize that if they do not interact with people in the new environment, they are unlikely to survive the study period and daily life. From all informants stated that they are trying to always communicate with new people so as to build a sustainable relationship.
"I'm talk with new people then in the future we can meet again, so we can be friends. Actually in Indonesia it is difficult to know this person is good. Because maybe it's fake. I often feel the need to be careful when I meet new people because I do not know if they will do good or bad things to me. I do not know what they say. I try to talk to know them and whether they are good for me"(Informant 3)

The efforts of Zimbabwean students by increasing interaction so as to establish relationships with new people are expected to reduce uncertainty by obtaining information about the new environment. This information search is done with initiatives to increase interaction by greeting and getting acquainted with others who approach it. Although the informants considered most Indonesians who did not speak English choose to remain silent and avoid interaction, Zimbabwean students continue to interact actively using English and hand signals for easy understanding. This strategy makes Zimbabwean students feel more confident, comfortable and faster to adjust to the environment because with the frequent interaction they will get used to and know the people around them. An increase in interaction with strangers will result in decreased anxiety and result in increased confidence to predict the behavior of others.

\section{Confidence to interact in interpersonal communication}

Confidence is one way that Zimbabwean students do to dare to start interacting and getting friends. Such confidence is a belief that an informant is capable of behaving as needed in his or her environment to achieve the desired result (Bandura, 1977). The characteristics of self-confident people are capable of being independent, selfless, tolerant, ambitious, optimistic, not shy, convinced by their own opinions and not exaggerated (Lauster, 1978).

"I just try to communicate with Indonesian people to know how their daily life and I get the knowledge, as 
I learn Indonesian and try to speak Indonesian although sometimes wrong but I am not afraid to start. As on the first time I tried talking to them I visited the tourist attraction in solo and inside the bus I found people then tried to ask with them" (Informant 1)

At an early stage in a new environment Zimbabwean students choose to travel around Solo such as Alun-alun, Keraton, and Shopping malls. They tend to choose entertainment events, but in the next stage, they prefer events to get more information about the environment in Indonesia (Toomey, 1999). Zimbabwean students use a network of friends that play an important role for migrants in terms of emotional support functions. The Indonesian as a host has an educative role by teaching the Indonesian language as well as providing the required information.

Informants trying to communicate using the Indonesian language although their Indonesian language skills are still lacking, they remain brave and confident to speak in Indonesian although sometimes there is a mistake in pronunciation. They want to show the people of Indonesia that they dare to speak foreign languages and expect Indonesians also want to dare to interact with them or teach them speak the correct language. Confidence is the basic capital of Zimbabwean students because without confidence, it will be difficult for them to adapt to new environments. Zimbabwean students are confident to start an interaction. Even tough the language barrier, Zimbabwean students remain active in greeting and socializing.

Even though self-confidence is identified with independence, highly self-confident people are generally more easily personally involved with others and more successful in interpersonal relations (Bunker, 1983). Zimbabwean students use self-confidence as their way of improving interpersonal relationships. The main problem in the anxiety of intercultural communication with a sense of worry about the response or judgment of others to their, that is about what he delivered and how he delivered it. This dependence on the judgment of others is one of the characteristics of the less self-confident (Lauster, 1978). The person confronts others is influenced by how they views theirself. One's interpersonal responses are often a reflection of their own cognition (Sudardjo \& Purnamaningsih, 2003).

"I can see they are happy with me and how they try to ask me." (Informant 3)

When informants try to get acquainted or greet, they can see the positive responds of the people in the neighborhood over them. This can affect the level of confidence Zimbabwean students in dealing with people in Indonesia.

\section{Discussion}

The findings of the research show similarities with some of the results of previous research in the journal entitled "Intercultural Friendship Development Between Finnish And International Students" (Peng, 2011) discusses factors affecting intercultural friendship relationships such as language, trust and mutuality. Language becomes an important factor influencing the formation of intercultural friendship. Some immigrants assume that language is a barrier for them to make friends with the host but on the other, language barriers can be overcome with a desire to get to know each other. In the previous journal (Peng, 2011) discusses that immigrants can not express themselves clearly and feel the pressure when communicating with others. Mutualism is a mutual benefit in the friendship relationship between immigrant and hosts by complementary needs and support Intercultural friendship starts from a lower stage such as greeting each other then to a higher level can be the meaning of a close friend based on their beliefs on friends.

One of the attempts by immigrants to reduce anxiety and uncertainty is to get friends from the local people so they can learn the language used in the environment by increasing their confidence. When immigrants experience anxiety about 
language differences, the information they get about their environment will be limited. But when immigrants choose to make friends, they can get information and reduce their anxiety and uncertainty (John, 2000).

In the theory of management anxiety and uncertainty (Grifin, 2006) explains in intercultural communication there are factors of relationship with foreigners that affect the level of anxiety and uncertainty. Immigrants are interested in establishing relationships from continuing introduction to friendship so that there is an increase in the sense of attraction of the immigrant to the people in the environment that will result in decreased anxiety and increased confidence in reducing behavioral uncertainty.

From the research result, immigrant effort in the management of anxiety and uncertainty with the people around their to communicate effectively is mindful management. Mindfulness as the ability of immigrants to reduce anxiety and uncertainty to the optimum stage so that ultimately able to achieve effective communication. Anxiety arises at an affective level that refers to feelings such as anxiety, confusion, stress of language differences that arise when they start dealing with strangers (Jandt, 2004). Mindful that immigrants need is communication skills that is how they attempt to increase interaction and confidently start interpersonal communication with the aim of developing friendship relationships in reducing the level of anxiety and uncertainty they experience. Mindful management by immigrants can build friendships of interpersonal communication that they do with strangers.

In friendship relationships, the host has a role to be able to support emotionally, actively provide assistance, maintain confidence and support (Wright, 1991). Patterns of friendship based on social needs or relief factors, where immigrants can benefit each other and information with the host that can reduce anxiety and uncertainty about the environment.

From the research results with the relationship of intercultural friendship, it can be related to the opinion from (Toomey, 1999) that interpersonal relation network refers to the combination of personal and social in which locals with immigrants have informationan to exchange. identity support and relational emphatic messages. Gain support of goals related to roles, and practical help. The information includes sharing knowledge and getting others to know a certain important news. So Immigrants use friendship networks as an important role for immigrants in terms of support functions. Establish friendships with a host that has an educative role as well as provide the required information thereby reducing the level of anxiety and uncertainty in immigrants (Toomey, 1999).

\section{E. CONCLUSION}

In the research of intercultural friendship relationships as a strategy to reduce anxiety and uncertainty of Zimbabwean students at the University Muhammadiyah of Surakarta, researchers divide the results of research into 5 categories. first, the language barrier as the cause of anxiety. Differences in everyday language used by newcomers to the community in the new environment cause anxiety to interact because Indonesians prefer to remain silent when they do not master the English language. Immigrants choose to make friends with the host so that they can learn the local language by increasing their confidence. second is the lack of information about the new environment as a cause of uncertainty. Immigrants experience anxiety about language differences making the information they getabout their environment will be limited, causing uncertainty about the conditions in their environment. Third is the relationship of friendship as a way to reduce anxiety and uncertainty. From the interviews with 3 informants said that by establishing friendships with Indonesian people they will get some benefits such as support, information assistance they need, and can learn the Indonesian language. By establishing friendships between 
immigrant cultures can reduce their anxiety and uncertainty. Fourth is to increase the intensity of communication to get friends. While experiencing culture shock, immigrants attempt to reduce the anxiety of differences by adapting and getting friends. To get friends they have to be active and dare to interact with new people to greet or get acquainted in order to develop an intercultural friendship relationship. And the fifth is the confidence to interact in interpersonal communications. Confidence is the basic principal for immigrants because without confidence, it will be difficult for them to adapt in a new environment. Zimbabwean students are confident to start interpersonal communication with new people they meet. Despite the obstacles of language migrants must remain active greet and socialize.

So from the results of research, The effort that done by migrants for new environments in the management of anxiety and uncertainty is by developing friendships. Immigrants use a network of friends that play an important role for migrants in terms of emotional support functions. Immigrants use mindful management in the form of communication skills that is how they attempt to increase interaction and confidently start interpersonal communication to get friends. By establishing friendships, the host will have an educative role by teaching the language as well as providing the information that needs for the immigrant. It states that immigrants can make that friendship relationship as a strategy to reduce anxiety and uncertainty in intercultural communication.The suggestion of the research is, this research only use interview and documentation as data collecting, for further research can be developed by using observation as method of data collecting.

\section{BIBLIOGRAPHY}

Albu. C.E. 2015. Intercultural Communication in Tourism, University of Lasi, Romania.

Chaer, A. 2007. Linguistik Umum. Jakarta: Rineka Cipta

Cupach, W.R., \& Imahori, T.1993. Identity Management Theory In R. L. Wiseman \& J. Koester Intercultural Communication Competence. Newbury Park, CA: Sage.

Destriadi, Y.2013. Manajemen Diri Untuk Mengelola Ketidakpastian dan Kecemasan Dalam Komunikasi antarbudaya Mahasiswa Kalimantan Barat.

Griffin, E.M. 2006. A First Look At Communication Theory, 6th Edition. New York: McGrawHill.

Huang, B.A.2008. Conceptualizations of Friendship between Chinese International Students and U.S. National. Faculty of Texas Tech University.

Kovalainen, N., \& Keisala,K. 2012. The Role of Shared Foreign Language in Intercultural Communication: A Case of Working Environments, Laurea University of Applied Sciences Keskikatu, Kerava, Finland.Vol. 2 No. 20.

Lee, P.W 2008. Stages and Transitions of Relational Identity Formation in Intercultural Friendship: Implications for Identity Management Theory. Journal of International and Intercultural Communication. Vol.1, No. 1 pp: 51-69.

Li, Z.F.2010. Bridging the Gap: Intercultural Friendship between Chinese and Americans. Master thesis.

Liliweri, A. 2001. Gatra-Gatra Komunikasi Antar Budaya. Yogyakarta: Pustaka Pelajar.

Littlejohn, S.W., \& Foss, K.A. 2008. Theories of Human Communication. California, USA: Sage Publications. 
Mulyana, D. 2004. Komunikasi Efektif; Suatu Pendekatan Lintas Budaya. Bandung: Remaja Rosda Karya.

Mumbengegwi. 2015. Keterangan Dasar Negara Republik Zimbabwe. https://www.kemlu. go.id/harare/id/Pages/Zimbabwe.aspx (Accessed 1 januari 2018)

Nadiroh. 2011. Genjot program internasional, UMS promosi ke Afrika. http://www.solopos. com/2011/05/12/genjot-program-internasional-ums-promosi-ke-afrika-97626 (Accessed 12 November 2017).

Nurani, D. 2015. Komunikasi Antarbudaya Mahasiswa Thailand Dalam Proses Belajar Mengajar Di Kelas Farmakologi. Fakultas Farmasi Universitas Muhammadiyah Surakarta. Vol. VII. NO. 1.

Peng, F. 2011. Intercultural Friendship Development Between Finnish and International Students University of Jyväskyl, Finlandia.

Samovar, L., Porter, Richard. McDaniel, \& Edwin R.2010. Komunikasi Lintas Budaya, Salemba Humanika, Jakarta.

Siska, Sudardjo, \& Purnamaningsih, E.H. 2003. Kepercayaan Diri Dan Kecemasan Komunikasi Interpersonal Pada Mahasiswa Universitas Gadjah Mada.

Tubbs, Stewart, L., \& Moss. S. 2000. Human Communication, Remaja Rosda Karya, Bandung.

Utami, L. S. 2015. Teori-Teori Adaptasi Antar Budaya Fakultas Ilmu Komunikasi Universitas Tarumanagara Jakarta.

Wang, S., Sun, X., \& Liu, C. 2010. Intercultural Analysis of Communication Anxieties Encountered by International Students in the United States.

Wright, H.P., \& Scanlon, B.M.1991. Gender Role Orientations and Friendship: Some attenuation, But Gender Differences Abound. Sex Roles. Vol. 24, No.9/10, pp: 551-566. 